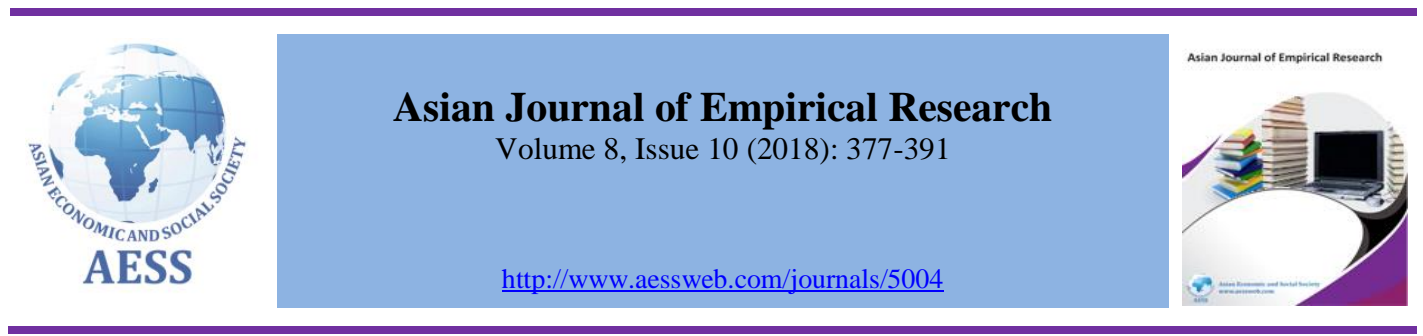

\title{
Differential impact of pay satisfaction dimensions on job performance and turnover intentions in pay for performance systems: The mediating role of affective commitment
}

\section{Shahina Javad , Premarajan R. K. $^{\mathrm{b}}$}

Assistant Professor; (OB \& HRM), Institute of Management Technology, Dubai, United Arab Emirates.

b Professor; (OB \& HRM), XLRI, Jamshedpur, India.

\. shahinajavad@gmail.com Corresponding author

\section{ARTICLE HISTORY:}

Received: $23-$ Sep-2018

Accepted: $15-\mathrm{Nov}-2018$

Online available: $30-\mathrm{Nov}-$

2018

\section{Keywords:}

Pay satisfaction dimensions, Performance,

Turnover,

Role of affective commitment

\begin{abstract}
The purpose of the present study was threefold. First, to test the validity of the dimensions of pay satisfaction in pay for performance systems. Second, to study the relative effects of different pay satisfaction dimensions on individual work outcomes. Third, to examine potential mediating role of affective commitment in the pay satisfaction-individual work outcome relationship. A twosample cross-sectional survey conducted among sales executives and sales managers of two different organizations offer support for the distinctiveness of four pay satisfaction dimensions viz., fixed pay level, variable pay level, pay structure and administration, and variable pay procedure satisfaction. The findings of path analyses indicated that the dimensions differentially predicted the outcome variables. The results reported that affective commitment was not a significant mediator between pay satisfaction dimensions and work outcomes, except between variable pay level satisfaction and job performance in the first sample. However, affective commitment was significantly related to turnover intentions. Implications for theory and practice are discussed.
\end{abstract}

\section{Contribution/ Originality}

Past research reported inconclusive relationship between pay satisfaction and job performance. The present study builds the gap in the literature by examining the effects of different pay satisfaction dimensions on job performance and turnover intentions in variable pay systems. The study also has implications for organizational justice literature.

DOI: 10.18488/journal.1007/2018.8.10/1007.10.377.391

ISSN (P): 2306-983X, ISSN (E): 2224-4425

How to cite: Shahina Javad and Premarajan R. K. (2018). Differential impact of pay satisfaction dimensions on job performance and turnover intentions in pay for performance systems: The mediating role of affective commitment. Asian Journal of Empirical Research, 8(10), 377-391.

(C) 2018 Asian Economic and Social Society. All rights reserved 


\section{INTRODUCTION}

Pay for performance (PFP) is suggested as an important determinant of employee attitudes, motivation and behavior (Gerhart and Milkovich, 1992; Gerhart and Rynes, 2003; Lazear 1996; 1999; 2000; Shaw et al. 2015). However, only a few empirical studies examined the impact of actual pay on employee performance and retention in PFP system. These studies found the relationship was weak at best (e.g. Gardner et al., 2004; Igalens and Roussel, 1999). This may be due to the methodological and measurement issues in linking amount of pay directly to individual work outcomes (Hauret and Williams, 2017; Shittu, 2008). For example, two employees receiving the same amount of pay may not exhibit the same level of motivation to perform or intention to stay with the employer.

According to compensation experts, amount of pay and work outcomes may be indirectly related through employee perceptions about the pay they received (Gerhart and Rynes, 2003; Lawler, 1971; Hauret and Williams, 2017; Miceli and Mulvey, 2000). Hence, researchers have examined the psychological mechanisms involved in the perception of pay in order to understand it's motivational and retention effects (Vandenberghe et al., 2008). Researchers have identified three such mediating mechanisms: organization based self-esteem (Gardner et al., 2004), organizational justice (Choi and Chen, 2007; Ismail and Shariff, 2008) and pay satisfaction (Lawler, 1971; Shantz et al., 2018; Williams et al., 2008) While organization based self-esteem and organizational justice are influenced by a number of other organizational factors in addition to pay (Pierce and Gardner, 2004), pay satisfaction is determined by pay (Heneman and Schwab, 1985; Miceli and Lane, 1991; Williams et al., 2008) Earlier models considered pay satisfaction as a unidimensional construct. Later, based on cognitive differentiation and administrative independence arguments, Heneman (1985) and Heneman and Schwab (1985) conceptualized pay satisfaction as a multidimensional construct. Incorporating organizational justice principles, Miceli and Lane (1991) further extended Heneman and Schwab's (1985) model along "outcome versus process" dichotomy. Miceli and Lane (1991) argued that employees' satisfaction with pay outcomes could be distinguished from their reactions to the process used in determining the outcomes. However, both the models were developed to study pay satisfaction in fixed pay system context, thus, they failed to capture pay satisfaction in PFP systems.

The research interest in compensation satisfaction is also due to its potential influence on employee attitudes and behavior. As pay satisfaction is expected to gauge compensation plan effectiveness (Heneman et al., 1997), it seems likely that employee satisfaction with outcome and process aspects in PFP systems may strongly influence work outcomes. For example, Lawler (1971) and Weiner (1980) noted that employees' dissatisfaction with pay under a PFP plan may affect job performance and turnover. Yet, little research attention has been made to examine the differential impact of pay satisfaction/dissatisfaction on job performance and turnover in PFP systems.

Pay satisfaction may be indirectly related to individual outcomes through organizational commitment (Vandenberghe and Tremblay, 2008). Favorable rewards and fair pay procedures may influence the extent to which employees believe that the organization is committed to them (Miceli and Mulvey, 2000) which in turn contribute to employee commitment to the organization (Williams et al., 2008). Moreover, employee commitment to organization is expected to influence both employee production and participation behaviors. This may be because those committed to organization may be likely to work harder and less likely to leave the organization (Meyer and Allen, 1991). Of different dimensions of commitments, affective commitment was found to be strongly related to pay satisfaction (Miceli and Mulvey 2000; Rhoades et al., 2001) and work outcomes (Rhoades et al., 2001; Meyer et al., 2002; Siders et al., 2001). However, little research attention has been paid to examine the mediating role of affective commitment in pay satisfaction- work outcomes relationship. To address the above noted gaps in the literature, we developed and tested a multidimensional model of pay satisfaction in PFP systems. Our study intends to contribute to the pay satisfaction literature by (1) exploring dimensionality of pay satisfaction in a certain context, i.e. PFP system (2) examining whether pay satisfaction dimensions have differential effects on two important individual work outcomes relevant 
to organizations i.e. job performance and turnover intentions and (c) examining the mediating role of affective commitment, if any, in the pay satisfaction-work outcome relationship.

\section{LITERATURE REVIEW}

\subsection{Types of pay systems}

A number of reward systems have been designed to motivate employee performance and participation behaviors (Beer and Spector, 1985; Gerhart and Milkovich, 1990). Broadly, pay systems fall into two categories: fixed pay and PFP systems. Fixed pay system links pay to skills, competencies or time which employees invest in their work (Heneman and Gresham, 2002; Milkovich et al., 2009). As people receive similar pay increases regardless of individual or firm performance, pay will do little to motivate performance in fixed pay system. Hence, a large number of organizations have moved pay for performance system. In PFP systems, direct orcash compensation includes two distinct forms of pay such as fixed/base pay and variable/incentive pay (Milkovich et al., 2009; Durham and Bartol, 2000). Fixed pay provides the minimum level of security for the employee while variable pay provides incentive for better performance (Kurland, 1991).

Moreover, PFP plans differ in terms of reward contingency or pay mix among different organizations and different jobs within the same organization (Gerhart et al., 1995). Pay mix decisions focus on the relative emphasis an organization places on fixed pay and variable pay (Bloom and Milkovich, 1998; Gomez-Mejia et al., 2004; Igalens and Roussel, 1999). Based on the degree of pay mix, PFP plans may be classified into low contingent pay, moderate contingent pay and maximally contingent pay (Harrison et al., 1996). In low contingent rewards, only a small percentage of pay results from performance. In moderate and maximally contingent reward, a larger percentage of total pay results from performance (Shaw and Gupta, 2007). Both non- contingent rewards (100 percent guaranteed pay) and maximally contingent rewards (100 percent pay at risk) are extreme pay strategies. Whereas, low and moderate reward contingencies aim to elicit the combined impact of different pay forms on motivation commitment and job engagement (Armstrong and Murlis, 2005).

\subsection{Pay satisfaction dimensions and measures}

The importance of pay on employee work attitudes was not recognized until psychologists and behavioral scientists became interested in pay satisfaction as a separate topic (Shapiro and Wahba, 1978). In the initial years pay satisfaction was studied as part of job satisfaction (Judge, 1993; Locke, 1983; Williams et al. 2007). Originating from the earlier work of Lawler (1971), satisfaction with pay has been a separate issue of concern (Heneman, 1985; Scarpello and Carraher, 2008; Williams et al., 2007). The earliest models of pay satisfaction- equity and discrepancy models- considered it as a unidimensional construct (Carraher and Buckley, 1996; Dyer and Theriault, 1976; Miceli and Lane, 1991; Weiner, 1980; Williams et al., 2007). Later, based on administrative independence argument, Heneman (1985) suggested that employees not only have a general affect towards their pay but also develop specific attitudes toward distinct aspects of pay such as level, structure, raise, and benefit (Heneman and Schwab, 1985).

Drawing from procedural justice principles, some researchers advocated that perceived fairness of the processes used to determine compensation may also influence employee satisfaction with pay Dyer and Theriault, 1976). In consistent with this, Miceli and Lane (1991) extended Heneman and Schwab's (1985) multidimensional model of pay satisfaction along outcome vs. system dichotomy. The new model distinguishes employee satisfaction with amount of pay (i.e. level/outcome) from satisfaction with system (i.e. procedures/processes) (Miceli and Mulvey, 2000). This has resulted into four pay satisfaction dimensions viz. pay level satisfaction, pay system satisfaction, benefit level, and benefit system satisfaction (Mulvey, 1991). Since, earlier pay satisfaction models were developed to study pay satisfaction in fixed pay systems, they underrepresent pay satisfaction domain in PFP context. 
A major distinguishing feature of PFP system is that it includes variable pay as part of total pay in addition to fixed pay. Some researchers attempted to build the gap by developing new models and scales suitable for measuring pay satisfaction in different types of variable pay systems. For example, Igalens and Roussel (1999) developed a theoretical model of pay satisfaction with fixed pay level and flexible pay level as separate dimensions of direct compensation. Later, Sturman and Short (2000) developed a lump sum bonus scale to supplement PSQ for pay systems with lump sum bonus. Likewise, Fong and Shaffer (2003) developed a group incentive satisfaction scale to indicate employee satisfaction with group incentives as a separate dimension of pay satisfaction. However, these scales focused on satisfaction with outcome related aspects of pay, and thus, failed to capture satisfaction with processes by which the outcomes are determined.

Mulvey et al. (2002) were among the first to develop a model to measure employee satisfaction with outcomes and processes aspects of pay. However, the model as well failed to include satisfaction with variable pay process. Later, Williams et al. (2008) developed a comprehensive model of pay satisfaction by integrating earlier multidimensional pay satisfaction models. Though the model included variable pay process satisfaction dimension, it included pay raise satisfaction to represent employee satisfaction with variable pay level. Conceptually pay raise is different from variable pay or incentives. Additionally, the model included satisfaction with total pay level as a complementary dimension. Since variable pay is part of total pay, variable pay level satisfaction and total pay level satisfaction may be confounding variables. Moreover, the model did not make a distinction between satisfaction with fixed pay and variable pay.

\section{HYPOTHESES AND MODEL DEVELOPMENT}

\subsection{Dimensionality of the direct compensation satisfaction in variable pay systems}

In both low and medium contingents pay plans (Harrison et al., 1996), pay forms include fixed pay as well as variable pay. Variable pay is administratively independent, and thus, may be perceived as a distinct component by the employees (Sturman and Short, 2000). Performance-based pay plan has performance evaluation process and reward allocation process (St-Onge, 2000). Hence, drawing on distributive and procedural justice theories, researchers suggest that pay satisfaction in such systems includes satisfaction with outcome received and satisfaction with process involved in allocating those outcomes (Bhal and Gulati, 2007; Miceli and Mulvey, 2000; Mulvey, 1991; Mulvey et al., 2002).

Integrating pay satisfaction and organizational justice literatures, pay satisfaction may have two outcome-oriented (fixed pay level and variable pay level) and two process-oriented (pay structure and administration and variable pay procedure satisfaction) dimensions in PFP systems. Therefore, we propose:

Hypothesis 1 (H1): The four dimensions of pay satisfaction (fixed pay level variable pay level pay structure \& administration and variable pay procedures) will be empirically distinguishable in pay for performance systems.

\subsection{Pay satisfaction dimensions and job performance}

Pay being an important aspect of job, a potential linkage between pay satisfaction and job performance is assumed in the literature (Lawler, 1971; Williams et al., 2006). Proponents of expectancy and reinforcement theories propose that pay will influence performance only in PFP systems due to the explicit link between pay and performance in such systems. Belcher (1962) and Lawler (1971) advocated that pay satisfaction would be positively related to job performance only in pay systems where pay is based upon performance. In order for pay to be an important motivator there has to be variability in pay options across individuals of varying performance levels. Of different components of pay in PFP systems, variable pay level is expected to strongly influence job performance. Thus: 
Hypothesis 2 (H2): Variable pay level satisfaction will be more strongly and positively related to job performance than any other dimensions of pay satisfaction in PFP systems.

\subsection{Pay satisfaction dimensions and turnover intentions}

Satisfaction with pay can increase employees' desire to stay with an organization (Lawler, 1971; Memon et al., 2017; Mohamed et al., 2017; Porter and Steers, 1973; Singh and Loncar, 2010). This may be because an employee with a favorable attitude may not exhibit unfavorable behaviors (Ajzen and Fishbein, 1977). Consistent to this, three meta-analyses reported moderate negative correlation between pay satisfaction and turnover (Cotton and Tuttle, 1986; Griffeth et al., 2000; Williams et al., 2006). However, the studies included in the meta-analyses treated pay satisfaction as a general construct.

Fair pay procedure is a critical aspect of the quality of work life and is essential to good employeremployee relations. Accordingly, satisfaction with organizational rules and procedures may encourage employees to continue their membership with the organization, and in turn, less likely to quit. Hence, justice scholars have argued that process related aspects are likely to be more important in determining employee's reaction to organizations such as intention to stay/turnover than outcome related aspects (Lind and Tyler, 1988). Previous empirical studies found support for the relative effectiveness of process dimensions of pay satisfaction on turnover than outcome dimensions (Bhal and Gulati, 2007; Choi and Chen, 2007; Vandenberghe and Tremblay, 2008). We, thus, propose:

Hypothesis 3 (H3): The process related dimensions (i.e. pay structure/administration and variable pay procedure satisfaction) will be more strongly and negatively related to turnover intentions than the outcome related dimensions (i.e. fixed pay level and variable pay level satisfaction) of pay satisfaction in PFP systems.

\subsubsection{Pay satisfaction and affective commitment}

Organization support theory (Eisenberger et al., 1986) and social exchange theory (Blau, 1964) together explain how pay satisfaction influences employees' emotional commitment to organization. As per organizational support theory employees' perceptions of the organization's commitment to them, referred as perceived organizational support (POS), are based on their global beliefs concerning the extent to which the organization values their contributions and cares about their wellbeing (Shore and Wayne, 1993). Social exchange view suggests that employees' inferences about the organization's commitment contribute to their subsequent commitment to the organization widely referred as organizational commitment (Shore and Tetrick, 1991). Since pay satisfaction indicates employee perceptions of the exchange relationship (Miceli and Mulvey, 2000), it may contribute to POS which in turn may influence affective commitment (Rhoades and Eisenberger, 2001; Panaccio et al., 2014; Tarigan and Ariani, 2015). Moreover, because POS is empirically related to both pay satisfaction (Miceli and Mulvey, 2000; Williams et al., 2008) and organizational commitment (Eisenberger et al., 1990; Rhoades et al., 2001), it could also be logically inferred that pay satisfaction and organizational commitment are related constructs. In consistent with this, past research empirically demonstrated that pay satisfaction and affective commitment are related constructs (e.g. Cohen and Gattiker, 1994; Dhawan and Mulla, 2011; Fu et al., 2011; Mathieu and Zajac, 1990 etc.). However, these studies focused on overall pay satisfaction. Schreurs et al. (2015) found that pay level satisfaction is related to affective commitment. This study also did not include process related dimensions of pay satisfaction.

The differential effects of pay satisfaction dimensions on affective commitment may be explained using direct effects or two-factor model of organizational justice. As per this model, while distributive (outcome) justice predicts personal-level outcomes, procedural (process) justice is more useful in predicting system-referenced attitudes (Konovsky, 2000; McFarlin and Sweeney, 1992). Affective commitment being a system-reference variable, procedural justice may be more important predictor than distributive justice (Colquitt et al., 2001). Therefore, we predict: 
Hypothesis 4 (H4): Process related dimensions (i.e. pay structure/administration and variable pay procedure satisfaction) will be positively and more strongly related to affective commitment than level related dimensions of pay satisfaction (i.e. fixed pay level and variable pay level satisfaction) in PFP systems.

\subsubsection{Affective commitment as a mediator}

Three meta-analytic reviews (Cohen and Gattiker, 1994; Mathieu and Zajac, 1990; Williams et al., 2007) indicate that pay satisfaction and organizational commitment are related constructs. Affective commitment is a response to positive work experiences (Meyer and Allen, 1991). Moreover, affective commitment was found to be related to objective measures of job performance (Siders at al., 2001) and turnover/turnover intentions (Meyer et al., 2002; Rhoades et al., 2001). Based on Baron and Kenny's (1986) mediating logic, it is hypothesized that the effects of pay satisfaction dimensions on job performance and intention to turnover may be mediated through affective commitment. Thus:

Hypothesis 5 (H5): Affective commitment will be positively related to objective measures of job performance.

Hypothesis 6 (H6): Affective commitment will be negatively related to turnover intentions.

Hypothesis $7 a(H 7 a)$ : Affective commitment will partially mediate the effects of pay satisfaction dimensions on job performance.

Hypothesis $7 b(H 7 b)$ : Affective commitment will partially mediate the effects of pay satisfaction dimensions on turnover intention.

\section{METHODOLOGY}

The target population for this study consisted of field salesforce working in different branches of the companies located in a metropolitan city in India. A survey was administered among salespeople in two different organizations working under differing reward contingencies. The first sample included sales managers from a financial services company. They were under a moderately contingent reward system: a large part of their total pay was in the form of incentives. There was no ceiling or limit on the incentives. The second sample included sales executives from a telecommunication company. They were under a low contingent reward system: a large part of their total pay was base pay. Variable pay percentage ranged from $10 \%$ to $20 \%$ of base pay. The incentive was based on meeting individual sales targets. However, the sample was made homogenous with respect to two aspects: organizational level and performance measures. In both companies the selected category of job was an entry-level position and the incentive was determined based on objective performance measure i.e. number of items sold.

In the first company out of 280 questionnaires distributed 178 questionnaires were returned. 24 responses had excessive missing data and hence they were eliminated by employing list-wise deletion approach. The overall response rate was 55\%. In the second company out of 220 questionnaires distributed 163 questionnaires were returned. 21 questionnaires were eliminated using list-wise deletion method due to missing data. The overall response rate was $64.5 \%$.

Data regarding pay satisfaction affective commitment and turnover intention was collected from the employees through the use of previously developed multi-item self-report measures. Responses ranged from $1=$ strongly disagree to $5=$ strongly agree. The wordings of the measures were modified to suit different pay components. The employer provided data on employee job performance.

Fixed pay level satisfaction was measured using 3-item from the pay level satisfaction scale (Heneman and Schwab, 1985). Pay structure and administration satisfaction was measured using 6-item scale 
adapted from Mulvey et al. (2002) and Williams et al. (2008). Variable pay level satisfaction was measured using 3-item scale adapted from Heneman and Schwab (1985). Variable pay procedures satisfaction was measured using 3-item scale developed by Williams et al. (2008). Affective commitment was assessed using 8- item developed by Allen and Meyer (1990). Turnover intention was assessed using 3-item scale developed by Cammann et al. (1983). The scale was widely used in the past. Respondents' job performance data was collected from the organizational records. Job performance was measured as percentage of sales quota achieved.

\section{RESULTS}

\subsection{Descriptive statistics}

Table 1(a) and 1(b) present the means, standard deviations, inter-correlations, and reliabilities of all variables for sample 1 and sample 2 respectively. Analysis of the inter-correlations among independent variables indicate that none of the correlations are above 0.90, and hence, the problem of multicollinearity is low (Hair et al., 2009). Reliability assessments for all the scales exceeded the minimum standard of .70 as suggested by Nunnally (1978).

\subsection{Theoretical model analyses}

We followed the two-step approach to structural equation modeling suggested by Anderson and Gerbing (1988). In the first step a confirmatory measurement model that specifies the relations of the observed measures to their posited underlying constructs was estimated. In the second step a confirmatory structural model that specifies the causal relations of the constructs to one another was tested. The fit of both measurement and structural models was tested using SEM software AMOS 18.0.The analysis was based on maximum likelihood estimation.

The measurement model describes the relationship between latent variables and its observed measures where the latent variables are allowed to inter-correlate freely (Anderson and Gerbing, 1988; Hair et $a l ., 2009)$. Following Hair et al. 's (2009) recommendation, we have included multiple fit indices ( $\chi^{2}$, RMSEA, CFI, TLI, SRMR) to assess the adequacy of measurement models. The recommended cutoff values for the indices for establishing an acceptable fit include:

$\chi^{2}$ with $p$ value $>0.05 ; \mathrm{RMSEA} \leq 0.08 ; \mathrm{CFI} \geq 0.95 ; \mathrm{TLI} \geq 0.95 ; \mathrm{SRMR} \leq 0.08$ (Hair et al., 2009).

Table 1(a): Descriptive statistics and correlations for sample 1

\begin{tabular}{|c|c|c|c|c|c|c|c|c|c|c|}
\hline & & $\mathbf{M}$ & SD & 1 & 2 & 3 & 4 & 5 & 6 & 7 \\
\hline & Age & 30.260 & 4.559 & & & & & & & \\
\hline & Tenure & 27.292 & 13.792 & & & & & & & \\
\hline 1 & FPLS & 2.968 & 0.978 & & & & & & & \\
\hline 2 & PSAS & 3.082 & 0.656 & $0.404 * *$ & & & & & & \\
\hline 3 & VPLS & 3.180 & 0.830 & $0.495 * *$ & $0.255^{* *}$ & & & & & \\
\hline 4 & VPSS & 3.227 & 0.707 & $0.258 * *$ & 0.126 & $0.538 * *$ & & & & \\
\hline 5 & PS & 3.097 & 0.541 & $0.754 * *$ & $0.714 * *$ & $0.768 * *$ & $0.584 * *$ & & & \\
\hline 6 & $\mathrm{AC}$ & 3.242 & 0.681 & $0.300 * *$ & 0.092 & $0.459 * *$ & $0.354 * *$ & $0.396 * *$ & & \\
\hline 7 & TI & 2.639 & 1.013 & $-0.495 * *$ & $-0.242 * *$ & $-0.538 * *$ & $-0.454 * *$ & $-0.575^{* *}$ & $-0.576 * *$ & \\
\hline 8 & $\begin{array}{l}\text { Job } \\
\text { Performance }\end{array}$ & 1.398 & 0.561 & $0.302 * *$ & 0.078 & $0.453 * *$ & $0.254 * *$ & $0.365 * *$ & $0.360 * *$ & $-0.344 * *$ \\
\hline
\end{tabular}

** Correlation is significant at the 0.01 level (2-tailed); *.Correlation is significant at the 0.05 level (2-tailed)

Table 1(b): Descriptive statistics and correlations for sample 2

\begin{tabular}{lccccccccc} 
& $\mathbf{M}$ & SD & $\mathbf{1}$ & $\mathbf{2}$ & $\mathbf{3}$ & $\mathbf{4}$ & $\mathbf{5}$ & $\mathbf{6}$ & $\mathbf{7}$ \\
\hline Age & 31.105 & 4.887 & & & & & & & \\
Tenure & 30.443 & 16.408 & & & & & & & \\
\hline
\end{tabular}




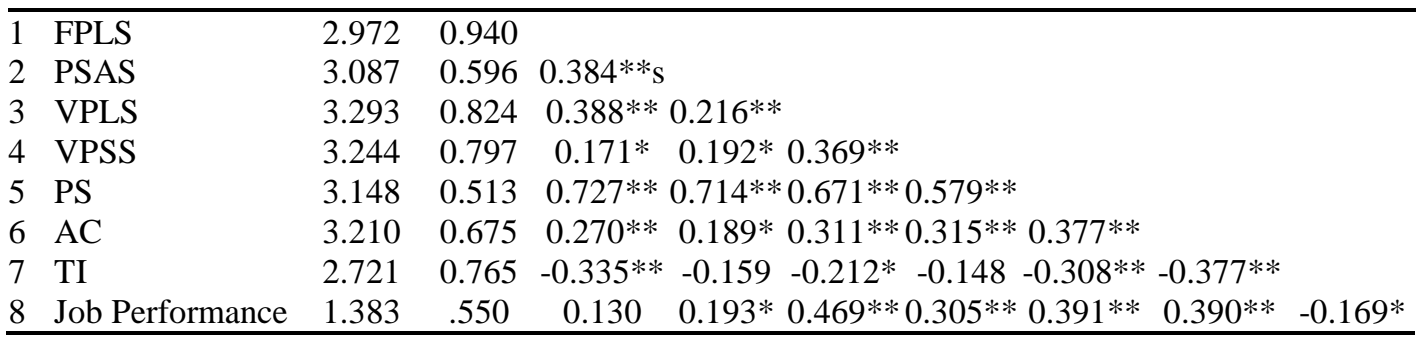

** Correlation is significant at the 0.01 level (2-tailed); *Correlation is significant at the 0.05 level (2-tailed)

Table 2: Fit indices of the confirmatory factor analysis of pay satisfaction dimensions

\begin{tabular}{|c|c|c|c|c|c|c|c|}
\hline & $\chi^{2}$ & Df & CFI & RMSEA & TLI & SRMR & $\Delta \chi^{2}(\Delta d f)^{c}$ \\
\hline \multicolumn{8}{|l|}{ Sample 1} \\
\hline 1 factor & $944.435 * *$ & 90 & 0.479 & 0.245 & 0.392 & 0.219 & \\
\hline 2 factors $^{a}$ & $575.900 * *$ & 89 & 0.703 & 0.189 & 0.650 & 0.188 & $368.535 * *(1)$ \\
\hline 3 factors ${ }^{b}$ & $209.174 * *$ & 87 & 0.925 & 0.096 & 0.910 & 0.067 & $366.726 * *(2)$ \\
\hline 4 factors & $143.525 * *$ & 84 & 0.964 & 0.068 & 0.955 & 0.049 & $65.649 * *(3)$ \\
\hline \multicolumn{8}{|l|}{ Sample 2} \\
\hline 1 factor & $614.053 * *$ & 90 & 0.500 & 0.203 & 0.417 & 0.169 & \\
\hline 2 factors $^{a}$ & $412.686 * *$ & 89 & 0.691 & 0.161 & 0.636 & 0.150 & $201.367 * *(1)$ \\
\hline 3 factors $b$ & $206.737 * *$ & 87 & 0.886 & 0.099 & 0.862 & 0.096 & $205.949 * *(2)$ \\
\hline 4 factors & $106.327 * *$ & 84 & 0.979 & 0.043 & 0.973 & 0.047 & $100.410 * *(3)$ \\
\hline
\end{tabular}

$* * \mathrm{p}<0.01$

${ }^{a}$ combining pay structure and administration, variable pay level, and variable pay system.

${ }^{\mathrm{b}}$ combining variable pay level and variable pay system.

${ }^{c} \Delta \chi^{2}$ reports $\chi^{2}$ differences between the target model and the closest one in the sequence of nested models; $\Delta \mathrm{df}$ reports difference in the degrees of freedom between the target model and the closest nested model.

Note: $\chi^{2}$, chi-square; $d f$, degrees of freedom; CFI, comparative fit index; RMSEA, root mean square error of approximation; TLI, Tucker-Lewis index; SRMR, standardized root mean square residual.

The fit indices of overall measurement model for sample $1\left(\chi^{2}=391.552 ; \mathrm{df}=284 ; p<0.01 ; \mathrm{RMSEA}=\right.$ $0.050 ; \mathrm{CFI}=0.965 ; \mathrm{TLI}=0.959 ; \mathrm{SRMR}=0.048)$ and sample $2\left(\chi^{2}=336.261 ; \mathrm{df}=284 ; p=0.018\right.$;

RMSEA $=0.036 ; \mathrm{CFI}=0.973 ; \mathrm{TLI}=0.969 ; \mathrm{SRMR}=0.055)$ indicated that measurement models fit the data well. Since $\chi^{2}$ statistics for both the measurement models were significant, we included two additional fit indices such as Chi-square by degrees of freedom ratio (Cmin) and incremental fit index (IFI) to further test the adequacy of the measurement model (Bentler, 1990; Hair et al., 2009). IFI above 0.90 and $\chi^{2} / \mathrm{df}$ less than 2 indicate a good fit. The resulting indices suggest an acceptable fit IFI $=0.965$ and $\chi^{2} / \mathrm{df}=1.379$ (sample 1 ) and IFI $=0.973$ and $\chi^{2} / \mathrm{df}=1.184$ (sample 2). Taken together the measurement model with 26 items fit the data well in both the samples.

Structural model specifies how the model constructs are related to each other. Structural models were estimated in the next stage to test the hypothesized relationships among the modeled constructs. In the structural model pay satisfaction was treated as exogenous variable job performance and turnover intention as endogenous variables and affective commitment as mediator variable. The fit indices for the structural model for study $1\left(\chi^{2}=447.685\right.$; $\mathrm{df}=316$; $\mathrm{p}<.01$; CFI= 0.957; TLI= 0.952; RMSEA= $\left.0.052 ; \mathrm{SRMR}=0.0671 ; \chi^{2} / \mathrm{df}=1.417 ; \mathrm{IFI}=0.958\right)$ and study $2\left(\chi^{2}=392.545 ; \mathrm{df}=316 ; \mathrm{p}<.01\right.$; $\left.\mathrm{CFI}=0.961 ; \mathrm{TLI}=0.957 ; \mathrm{RMSEA}=0.048 ; \mathrm{SRMR}=0.0702 ; \chi^{2} / \mathrm{df}=1.242 ; \mathrm{IFI}=0.962\right)$ indicated that the model fits the data well.

\subsection{Hypothesis testing}

Hypothesis 1 predicted that the proposed four dimensions of pay satisfaction would be empirically distinguishable. A confirmatory factor analysis was conducted to establish the distinctiveness of the 
four dimensions of pay satisfaction. Several measurement models were tested collapsing two or more factors into one. First a 1-factor model combining all 15 items measuring pay satisfaction construct was tested. Then a 2-factor model combining pay structure/administration, variable pay level and variable pay procedure scales into one was tested. In the next step a 3-factor model combining variable pay level and variable pay procedure scales into one was tested. Lastly a 4-factor model with four independent dimensions of pay satisfaction was tested. The fit indices of 1-factor 2-factor and 3-factor models were compared with the hypothesized 4-factor model. The 4-factor model yielded the following fit indices: $\chi^{2}=143.525$; $\mathrm{df}=84 ; p<0.01$; CFI= 0.964; TLI=0.955; RMSEA=0.068; $\mathrm{SRMR}=0.049$ (sample 1) and $\chi^{2}=106.327$; $\mathrm{df}=84 ; p=0.050$; $\mathrm{CFI}=0.979$; $\mathrm{TLI}=0.973$; RMSEA= 0.043 ; SRMR $=0.047$ (sample 2). The $\Delta \chi^{2}$ fit index indicated that model fit improved with increase in the number of factors. For both samples the results showed that the 4-factor model fit the data significantly better than various 3 -factor 2 -factor and 1-factor models. The selected fit indices of the four models for both samples are shown in Table 2. Further, a second-order pay satisfaction model was tested to determine whether an overall pay satisfaction construct exists as a higher order latent construct of the proposed four dimensions namely fixed pay level pay structure and administration variable pay level and variable pay procedure satisfaction. The fit indices for the second-order pay satisfaction model were acceptable in sample $1\left(\chi^{2}=161.600 ; \mathrm{df}=86 ; \mathrm{p}<.01 ; \mathrm{CFI}=.954\right.$; TLI= 0.944; RMSEA $=0.076$ sample 1) and the fit indices were excellent in sample $2\left(\chi^{2}=118.152\right.$; $\mathrm{df}=86$; $\mathrm{CFI}=0.969$; $\mathrm{TLI}=0.963 \mathrm{RMSEA}=0.051$ sample 2). Results also suggest that it is possible to conceptualize overall pay satisfaction as a second-order construct. Thus, hypothesis 1 was supported. The path coefficients between constructs in partially mediated model for both samples are shown in Figure 1. The path coefficients for sample 2 are shown in parentheses.

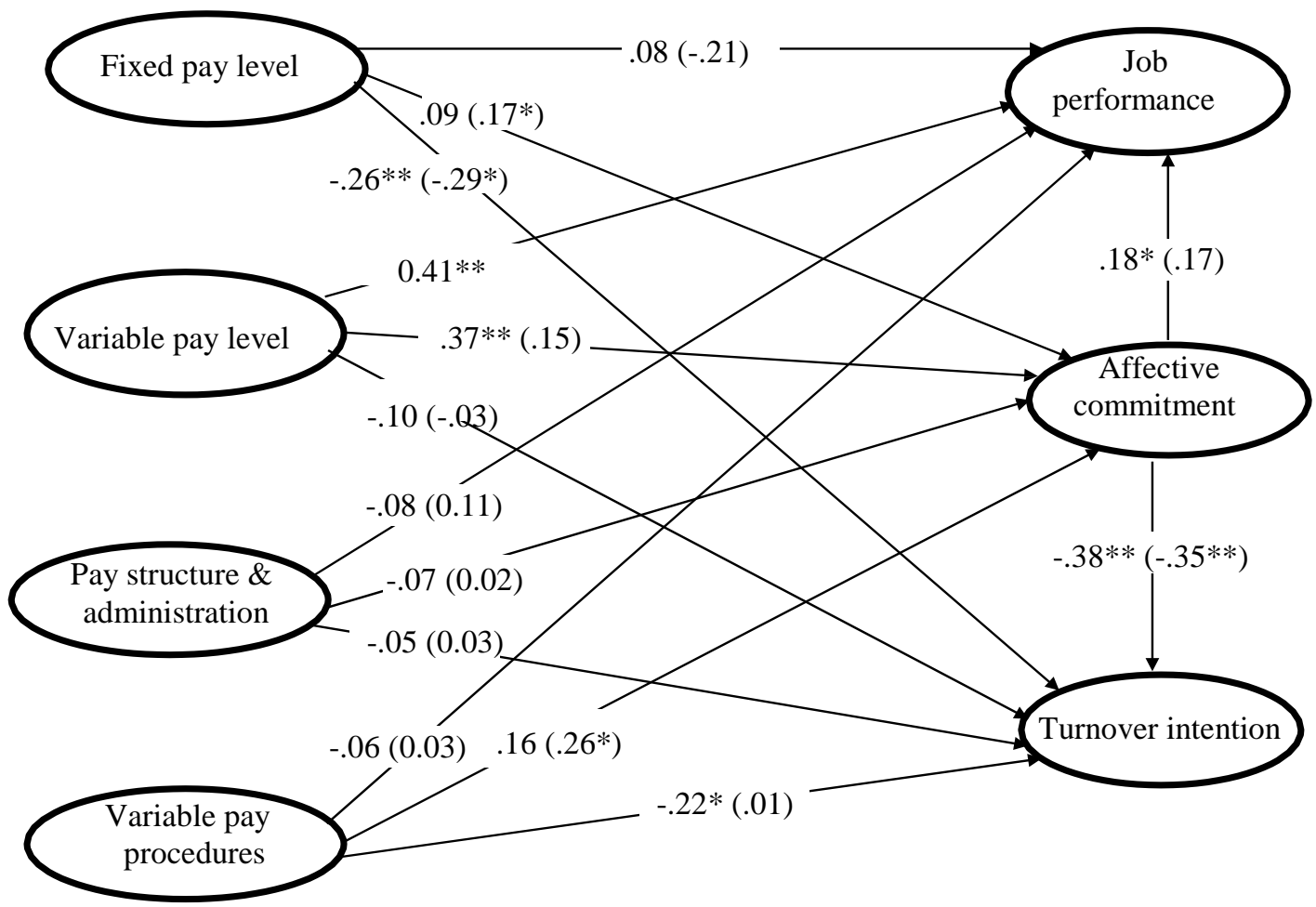

Figure 1: Path Coefficients for the multiorganizational samples. Sample 2 values are in parentheses while those for sample one are not

$* * \mathrm{p}<0.01 ; * \mathrm{p}<0.05$

Hypothesis 2 predicted that of different dimensions of pay satisfaction variable pay level satisfaction would be the strongest predictor of job performance. The path between variable pay level satisfaction 
and job performance was the only significant path in both samples: Sample $1(\beta=0.412 \mathrm{p}<.01)$ and sample $2(\beta=0.533 \mathrm{p}<.01)$. Thus, hypothesis 2 was well supported in both samples.

Hypothesis 3 predicted that process dimensions of pay satisfaction would be strong predictors of turnover intentions. In the first sample fixed pay level satisfaction and variable pay procedures satisfaction was significantly and negatively related to turnover intentions. However, the relationship was stronger for fixed pay level satisfaction $(\beta=-0.262 \mathrm{p}<.01)$ than variable pay procedures satisfaction $(\beta=-0.285 \mathrm{p}<.05)$. In the second sample turnover intentions was significantly and negatively related to fixed pay level satisfaction only $(\beta=0.262 \mathrm{p}<.01)$. Thus, hypothesis 3 was not supported by the results.

Hypothesis 4 predicted process dimensions of pay satisfaction would be better predictor of affective commitment. Variable pay level satisfaction was significantly related to affective commitment in sample $1(\beta=0.372 \mathrm{p}<.01)$. Whereas variable pay procedures was significantly and positively related to affective commitment $(\beta=0.256 \mathrm{p}<.05)$ in sample 2 . Hypothesis 4 was, thus, partially supported from the results.

Hypothesis 5 predicted that affective commitment would be positively related to objective measures of performance. While the standardized coefficient between affective commitment and job performance was significant for sample $1(\beta=0.179, \mathrm{p}=0.047)$ the relationship was not significant for sample $2(\beta=0.166 \mathrm{p}=.057)$. Hypothesis 5 was, thus, partially supported.

Hypothesis 6 predicted a negative relationship between affective commitment and turnover intentions in variable pay systems. The standardized path coefficients between affective commitment and turnover intentions was negative and significant for both samples $(\beta=-0.384 ; \mathrm{p}<.01$ for sample 1 ; and $\beta=-0.349 ; \mathrm{p}<.01$ for sample 2 ). Therefore, hypothesis 6 was supported. Two nested models, a partially mediated model and a fully mediated model, were compared to examine the type of mediation. In the fully mediated model pay satisfaction is expected to influence job performance and turnover intentions only through affective commitment. Whereas in the partially mediated model a direct relationship between pay satisfaction and dependent variables is assumed. The fully mediated model for sample $1\left(\chi^{2}=475.724 ; \mathrm{df}=313 ; \mathrm{p}<0.01 ; \mathrm{CFI}=0.947\right.$; TLI= 0.941; RMSEA=0.058) and sample $2\left(\chi^{2}=401.591 ; \mathrm{df}=313 ; \mathrm{p}<0.01 ; \mathrm{CFI}=0.955\right.$; TLI=0.949; RMSEA=0.045) produced acceptable fit. However, the partially mediated model for sample $1\left(\chi^{2}=415.668 ; \mathrm{df}=305 ; \mathrm{p}<.01\right.$; $\mathrm{CFI}=0.964$; TLI= 0.959; RMSEA=0.049) and sample $2\left(\chi^{2}=361.612 ; \mathrm{df}=305 ; \mathrm{p}<.05\right.$; CFI $=0.971$; $\mathrm{TLI}=0.967$; RMSEA=0.036) yielded better fit statistics as compared to fully mediated model. A $\chi^{2}$ difference test indicated that the partially mediated models produced significant improvement in model fit than fully mediated model in both samples $\Delta \chi^{2}=60.056 \mathrm{p}<.01$ ( sample 1) and $\Delta \chi^{2}=$ $39.979 \mathrm{p}<.01$ (sample 2).

\subsection{Implications}

The present study has implications for HR function. The findings of the study may provide guidelines to HR managers in designing and administering pay components particularly in objective performance based pay systems. The results suggest that managers interested in exploring employee satisfaction with pay must consider multidimensional nature of pay satisfaction. If performance improvement of sales personnel is a goal manager must address outcome aspects of compensation programs. Employees with high levels of variable pay satisfaction may exhibit higher job performance. Moreover, the findings that amount of pay and process determining pay differentials influence affective commitment and turnover intentions have effect on pay policy decisions. Furthermore, as affective commitment was also found to be a significant predictor of turnover intention, managers interested in retaining sales employees might look at factors fostering affective commitment. The literature suggests procedural justice and supervisor support as major work experiences, in addition to equitable organizational rewards, that may contribute to affective commitment. Since the results support 
differential impact of pay satisfaction dimensions on the outcomes included in the model, managers must explore the impact of pay satisfaction dimensions on other important work outcomes as well.

Funding: This study received no specific financial support.
Competing Interests: The authors declared that they have no conflict of interests.
Contributors/Acknowledgement: All authors participated equally in designing and estimation of current
research.
Views and opinions expressed in this study are the views and opinions of the authors, Asian Journal of
Empirical Research shall not be responsible or answerable for any loss, damage or liability etc. caused in
relation to/arising out of the use of the content.

\section{References}

Ajzen, I., \& Fishbein, M. (1977). Attitude-behavior relations: A theoretical analysis and review of empirical research. Psychological Bulletin, 84(5), 888-918. view at Google scholar / view at publisher

Allen, N. J., \& Meyer, J. P. (1990). The measurement and antecedents of affective continuance and normative commitment to the organization. Journal of Occupational Psychology, 63(1), 1-18. view at Google scholar / view at publisher

Anderson, J. C., \& Gerbing, D. W. (1988). Structural equation modeling in practice: A review and recommended two-step approach. Psychological Bulletin 103(3), 411-423. view at Google scholar / view at publisher

Armstrong, M., \& Murlis, H. (2005). Reward management: a handbook of remuneration strategy and practice. London: Kogan Page Limited. view at Google scholar

Baron, R. M., \& Kenny, D. A. (1986). The moderator-mediator variable distinction in social psychological research: conceptual strategic and statistical considerations. Journal of Personality and Social Psychology, 51(6), 1173-1182. view at Google scholar / view at publisher

Beer, M., \& Spector, B. (1985). Reward systems. In M. Beer and B. Spector (Eds.) Readings in Human Resource Management: 399-403, New York: Free Press.

Belcher, D. W. (1962). Wage and salary administration. New York: Prentice-Hall. https://books.google.ae/books/about/Compensation_administration.html?id=5cxDV1LE4AQ C\&redir esc $=\mathrm{y}$.

Bentler, P. M. (1990). Comparative fit indexes in structural models. Psychological Bulletin, 107(2), 238-246. view at Google scholar / view at publisher

Bhal, K. T., \& Gulati, N. (2007). Pay satisfaction of software professionals in India. Vikalpa: The Journal for Decision Makers, 32(3), 9-21. view at Google scholar

Blau, P. M. (1964). Justice in social exchange. Sociological Inquiry, 34(2), 193-206. view at Google scholar

Bloom, M., \& Milkovich, G. T. (1998). Relationships among risk incentive pay and organizational performance. Academy of Management Journal, 41(3), 283-297. view at Google scholar / view at publisher

Cammann, C., Fichman, M., Jenkins, G. D., \& Klesh, J. (1983). Michigan organizational assessment questionnaire. Assessing organizational change: A guide to methods measures and practices, 73(1), 71-138. view at Google scholar / view at publisher

Carraher, S. M., \& Buckley, M. R. (1996). Cognitive complexity and perceived dimensionality of pay satisfaction. Journal of Applied Psychology, 81(1), 102-109. view at Google scholar / view at publisher

Choi, J., \& Chen, C. C. (2007). The relationships of distributive justice and compensation system fairness to employee attitudes in international joint ventures. Journal of Organizational Behavior, 28, 687-703. view at Google scholar / view at publisher

Cohen, A., \& Gattiker, U. E. (1994). Rewards and organizational commitment across structural characteristics: A meta-analysis. Journal of Business and Psychology, 9(2), 137-157. view at Google scholar / view at publisher 
Colquitt, J. A., Conlon, D. E., Wesson, M. J., Porter, C., \& Ng, K. Y. (2001). Justice at the millennium: a meta-analytic review of 25 years of organizational justice research. Journal of applied psychology, 86(3), 425-445. view at Google scholar / view at publisher

Cotton, J. L., \& Tuttle, J. M. (1986). Employee turnover: a meta-analysis and review with implications for research. Academy of Management Review, 11(1), 55-70. view at Google scholar / view at publisher

Dhawan, V., \& Mulla, Z. (2011). The role of pay and leadership in developing organizational commitment. South Asian Journal of Management, 18(2), 60-75. view at Google scholar

Durham, C. C., \& Bartol, K. M. (2000). Pay for performance. Handbook of principles of organizational behavior, $2^{\text {nd }}$ Edition, 150-165. view at Google scholar / view at publisher

Dyer, L., \& Theriault, R. (1976). The determinants of pay satisfaction. Journal of Applied Psychology, 61(5), 596-604. view at Google scholar / view at publisher

Eisenberger, R., Fasolo, P., \& Davis-LaMastro, V. (1990). Perceived organizational support and employee diligence commitment and innovation. Journal of Applied Psychology, 75(1), 51- 59. view at Google scholar / view at publisher

Eisenberger, R., Huntington, R., Hutchison, S., \& Sowa, D. (1986). Perceived organizational support. Journal of Applied Psychology, 71(3), 500-507. view at Google scholar / view at publisher

Fong, S. C. L., \& Shaffer, M. A. (2003). The dimensionality and determinants of pay satisfaction: a cross-cultural investigation of a group incentive plan. International Journal of Human Resource Management, 14(4), 559-580. view at Google scholar / view at publisher

Fu, W., Deshpande, S. P., \& Zhao, X. (2011). The impact of ethical behavior and facets of job satisfaction on organizational commitment of Chinese employees. Journal of Business Ethics, 104(4), 1-7. view at Google scholar / view at publisher

Gardner, D. G., Van Dyne, L., \& Pierce, J. L. (2004). The effects of pay level on organization- based self-esteem and performance: A field study. Journal of Occupational \& Organizational Psychology, 77(3), 307-322. view at Google scholar / view at publisher

Gerhart, B. A., Minkoff, H. B., \& Olsen, R. N. (1995). Employee compensation: theory practice and evidence. CAHRS Working Paper Series. view at Google scholar

Gerhart, B., \& Milkovich, G. T. (1990). Organizational differences in managerial compensation and financial performance. Academy of Management Journal, 33(4), 663-691. view at Google scholar / view at publisher

Gerhart, B., \& Milkovich, G. T. (1992). Employee compensation. Research and Practice. In M. Dunnette, D., \& Hough, L. M. (Eds.), Handbook of industrial and organizational psychology, Vol. 3, Palo Alto CA: Consulting Psychologists Press. view at Google scholar

Gerhart, B., \& Rynes, S. L. (2003). Compensation: Theory evidence and strategic implications. Thousand Oaks CA: Sage Publications. view at Google scholar / view at publisher

Gomez-Mejia, L. R., Balkin, D. B., \& Cardy, R. L. (2004). Managing human resources. Prentice Hall Upper Saddle River. view at Google scholar

Griffeth, R. W., Hom, P. W., \& Gaertner, S. (2000). A meta-analysis of antecedents and correlates of employee turnover: Update moderator tests and research implications for the next millennium. Journal of Management, 26(3), 463-488. view at Google scholar / view at publisher

Hair, J. F., Black, W. C., Babin, B. J., Anderson, R. E., \& Tatham, R. L. (2009). Multivariate data analysis (Sixth ed.), New Delhi: Pearson Education. view at Google scholar

Harrison, D. A., Virick, M., \& William, S. (1996). Working without a net: time performance and turnover under maximally contingent rewards. Journal of Applied Psychology, 81(4), 331-345. view at Google scholar / view at publisher

Hauret, L., \& Williams, D. R. (2017). Relative income and pay satisfaction: Further evidence on the role of the reference group. Journal of Happiness Studies, 1-23. view at Google scholar / view at publisher

Heneman, III H. G. (1985). Pay satisfaction. In K. M. Rowland and G. R. Ferris (Eds.), Research in Personnel and Human Resource Management, 3, 115-139. Connecticut: Jai Press Inc. view at Google scholar 
Heneman, III H. G., \& Schwab, D. P. (1985). Pay satisfaction: its multidimensional nature and measurement. International Journal of Psychology, 20(2), 129-141. view at Google scholar / view at publisher

Heneman, R. L., \& Gresham M. T. (2002). Performance-based pay plans. In R. L. Heneman (Eds.), Strategic Reward Management: Design Implementation and Evaluation, Greenwich: Information Age Publishers. view at Google scholar

Heneman, R. L., Porter, G., Greenberger, D. B., \& Strasser, S. (1997). Modeling the relationship between pay level and pay satisfaction. Journal of Business and Psychology, 12(2), 147-158. view at Google scholar

Igalens, J., \& Roussel, P. (1999). A study of the relationships between compensation package work motivation and job satisfaction. Journal of Organizational Behavior, 20(7), 1003-1025. view at Google scholar / view at publisher

Ismail, A., \& Shariff, M. N. M. (2008). Interactional justice between pay level job satisfaction and job performance within Malaysian institutions of higher learning. International Journal of Business and Management Science, 1(1), 67-83. view at Google scholar / view at publisher

Judge, T. A. (1993). Validity of the dimensions of the pay satisfaction questionnaire: Evidence of differential prediction. Personnel Psychology, 46, 331-355. view at Google scholar / view at publisher

Konovsky, M. A. (2000). Understanding procedural justice and its impact on business organizations. Journal of Management, 26(3), 489-511. view at Google scholar / view at publisher

Kurland, N. B. (1991). The ethical implications of the straight-commission compensation system- An agency perspective. Journal of Business Ethics, 10(10), 757-766. view at Google scholar / view at publisher

Lawler, III E. E. (1971). Pay and organizational effectiveness: a psychological view. New York: McGra-Hill Book Company. view at Google scholar / view at publisher

Lazear, E. P. (1996). Performance pay and productivity. National bureau of economic research Cambridge Mass. USA. view at Google scholar / view at publisher

Lazear, E. P. (1999). Output-based pay: incentives or sorting?. National bureau of economic research Cambridge Mass, USA. view at Google scholar / view at publisher

Lazear, E. P. (2000). Performance pay and productivity. The American Economic Review 90(5), 13461361. view at Google scholar / view at publisher

Lind, E. A., \& Tyler, R. T. (1988). The social psychology of procedural justice. Springer Science \& Business Media. view at Google scholar

Locke, E. A. (1983). The nature and causes of job satisfaction. In M. D. Dunnette (Ed.) Handbook of Industrial and Organizational Psychology, New York: John Wiley and Sons. view at Google scholar

Mathieu, J. E., \& Zajac, D. M. (1990). A review and meta-analysis of the antecedents correlates and consequences of organizational commitment. Psychological Bulletin, 108(2), 171-194. view at Google scholar / view at publisher

McFarlin, D. B., \& Sweeney, P. D. (1992). Research notes. Distributive and procedural justice as predictors of satisfaction with personal and organizational outcomes. Academy of Management Journal, 35(3), 626-637. view at Google scholar / view at publisher

Memon, M. A., Salleh, R., \& Baharom, M. N. R. (2017). The mediating role of work engagement between pay satisfaction and turnover intention. International Journal of Economics, Management and Accounting, 25(1), 43. view at Google scholar

Meyer, J. P., \& Allen, N. J. (1991). A three-component conceptualization of organizational commitment. Human Resource Management Review, 1(1), 61-89. view at Google scholar / view at publisher

Meyer, J. P., Stanley, D. J., Herscovitch, L., \& Topolnytsky, L. (2002). Affective continuance and normative commitment to the organization: A meta-analysis of antecedents correlates and consequences. Journal of Vocational Behavior, 61(1), 20-52. view at Google scholar / view at publisher 
Miceli, M. P., \& Lane, M. C. (1991). Antecedents of pay satisfaction: a review and extension. In K. M. Rowland and G. R. Ferris (Eds.) Research in Personnel and Human Resources Management, Vol. 9: 235-309, Greenwich: Jai Press Inc. view at Google scholar

Miceli, M. P., \& Mulvey, P. W. (2000). Consequences of satisfaction with pay systems: Two field studies. Industrial Relations, 39(1), 62-87. view at Google scholar / view at publisher

Milkovich, G., Newman, J., \& Gerhart, B. (2017). Compensation. 12 $2^{\text {th }}$ edition, McGraw Hill Education, https://www.mheducation.co.uk/9781259532726-emea-compensation.

Mohamed, A. A., Mohamad, M. S., \& Awad, A. E. (2017). The relationship between pay satisfaction and turnover intention in Egypt. Journal of Competitiveness Studies, 25(1), 65- 79. view at Google scholar

Mulvey, P. W. (1991). Pay system satisfaction: an exploration of the construct and its predictors. The Ohio State University. view at Google scholar

Mulvey, P. W., LeBlanc, P. V., Heneman, R. L., \& McInerney, M. (2002). Study finds that knowledge of pay process can beat out amount of pay in employee retention organizational effectiveness. Journal of Organizational Excellence, 21(4), 29-42. view at Google scholar / view at publisher

Nunnally, J. (1978). Psychometric methods. McGraw-Hill Book Co.: New York. view at Google scholar / view at publisher

Panaccio, A., Vandenberghe, C., \& Ben Ayed, A. K. (2014). The role of negative affectivity in therelationships between pay satisfaction, affective and continuance commitment and voluntary turnover: A moderated mediation model. Human relations, 67(7), 821-848. view at Google scholar / view at publisher

Pierce, J. L., \& Gardner, D. G. (2004). Self-esteem within the work and organizational context: A review of the organization-based self-esteem literature. Journal of Management, 30(5), 591622. view at Google scholar / view at publisher

Porter, L. W., \& Steers, R. M. (1973). Organizational, work, and personal factors in employee turnover and absenteeism. Psychological Bulletin, 80(2), 151-176. view at Google scholar / view at publisher

Rhoades, L., \& Eisenberger, R., (2001). Perceived organizational support: a review of the literature. Journal of Applied Psychology, 87(4), 698-714. view at Google scholar

Rhoades, L., Eisenberger, R., \& Armeli, S. (2001). Affective commitment to the organization: The contribution of perceived organizational support. Journal of applied psychology, 86(5), 825. view at Google scholar / view at publisher

Scarpello, V., \& Carraher, S. M. (2008). Are pay satisfaction and pay fairness the same construct?. Baltic Journal of Management, 3123-39(1), 23-39. view at Google scholar

Schreurs, B., Guenter, H., van Emmerik, I. H., Notelaers, G., \& Schumacher, D. (2015). Pay level satisfaction and employee outcomes: the moderating effect of autonomy and support climates. The International Journal of Human Resource Management, 26(12), 1523-1546. view at Google scholar / view at publisher

Shantz, A., Wang, J., \& Malik, A. (2018). Disability status, individual variable pay, and pay satisfaction: Does relational and institutional trust make a difference?. Human Resource Management, 57(1), 365-380. view at Google scholar / view at publisher

Shapiro, H. J., \& Wahba, M. A. (1978). Pay satisfaction: an empirical test of a discrepancy model. Management Science, 24(6), 612-622. view at Google scholar / view at publisher

Shaw, J. D., \& Gupta, N. (2007). Pay system characteristics and quit patterns of good average and poor performers. Personnel Psychology, 60, 903-928. view at Google scholar / view at publisher

Shaw, J. D., \& Gupta, N. (2015). Let the evidence speak again! Financial incentives are more effective than we thought. Human Resource Management Journal, 25(3), 281-293. view at Google scholar / view at publisher

Shittu, O. (2008). Pay referent comparison and pay level satisfaction: Some differences among employees in the UK food retail sector. Management Research News, 31(7), 538-548. view at Google scholar / view at publisher

Shore, L. M., \& Tetrick, L. E. (1991). A construct validity study of the survey of perceived organizational support. Journal of Applied Psychology, 76(5), 637-643. view at Google scholar I view at publisher 
Shore, L. M., \& Wayne, S. J. (1993). Commitment and employee behavior: Comparison of affective commitment and continuance commitment with perceived organizational support. Journal of Applied Psychology, 78(5), 774-780. view at Google scholar / view at publisher

Siders, M. A., George, G., \& Dharwadkar, R. (2001). The relationship of internal and external commitment foci to objective job performance measures. Academy of Management Journal, 44(3), 570-579. view at Google scholar / view at publisher

Singh, P., \& Loncar, N. (2010). Pay satisfaction job satisfaction and turnover intent. Relations Industrielles/Industrial Relations, 65(3), 470-490. view at Google scholar / view at publisher

St-Onge, S. (2000). Variables influencing the perceived relationship between performance and pay in a merit pay environment. Journal of Business \& Psychology, 14(3), 459-479. view at Google scholar

Sturman, M. C., \& Short, J. C. (2000). Lump-sum bonus satisfaction: testing the construct validity of a new pay satisfaction dimension. Personnel Psychology, 53, 673-700. view at Google scholar / view at publisher

Tarigan, V., \& Ariani, D. W. (2015). Empirical study relations job satisfaction, organizational commitment, and turnover intention. Advances in Management and Applied Economics, 5(2), 21. view at Google scholar

Vandenberghe, C., \& Tremblay, M. (2008). The role of pay satisfaction and organizational commitment in turnover intentions: a two-sample study. Journal of Business Psychology, 22: 275-286. view at Google scholar / view at publisher

Vandenberghe, C., St-onge, S., \& Robineau, É. (2008). An analysis of the relation between personality and the attractiveness of total rewards components. Industrial Relations, 63(3), 425-450. view at Google scholar / view at publisher

Weiner, N. (1980). Determinants and behavioral consequences of pay satisfaction: A comparison of two models. Personnel Psychology, 33(4), 741-757. view at Google scholar / view at publisher

Williams, M. L., Brower, H. H., Ford, L. R., Williams, L. J., \& Carraher, S. M. (2008). A comprehensive model and measure of compensation satisfaction. Journal of Occupational \& Organizational Psychology, 81(4), 639-668. view at Google scholar / view at publisher

Williams, M. L., McDaniel, M. A., \& Nguyen, N. T. (2006). A meta-analysis of the antecedents and consequences of pay level satisfaction. Journal of Applied Psychology, 91(2), 392-413. view at Google scholar / view at publisher

Williams, M., McDaniel, M., \& Ford, L. (2007). Understanding multiple dimensions of compensation satisfaction. Journal of Business \& Psychology, 21(3), 429-459. view at Google scholar / view at publisher 